\title{
Back to the kitchen? Gender role attitudes in 13 East European countries
}

\section{Zurück in die Küche? Einstellungen zu Geschlechterrollen in 13 osteuropäischen Ländern}

\begin{abstract}
:
This paper explores the determinants of gender role opinions in 13 post-communist Eastern European societies using survey data from the project EUREQUAL. Our main findings consist of two parts. First, contrary to the expectations of scholars who emphasize the lack of gender/feminist consciousness in Eastern Europe, we argue that gender indeed is an important determinant of gender role opinions in post-communist societies: as elsewhere women express more liberal attitudes than men. Second, we argue that the interaction of other determinants of gender role opinions with gender also follows patterns described in the literature for more developed capitalist countries. In this respect, therefore, East European countries seem to fit the general trends of gender role opinion formation. As explanation we point to a connection between women's material conditions and their gender role attitudes, not denying the importance of cultural difference - if primarily as exception - to this process.
\end{abstract}

Key words: gender, gender role attitudes, Central and Eastern Europe, post-communism, gender inequality

\section{Zusammenfassung:}

Dieser Artikel untersucht, auf Basis von Umfragedaten des EUREQUAL-Projektes, die Determinanten von Einstellungen zu Geschlechterrollen in 13 postkommunistischen osteuropäischen Gesellschaften. Unsere Hauptergebnisse bestehen aus zwei Teilen. Erstens: Wir legen dar, dass - entgegen den Erwartungen von Wissenschaftler(inne)n, die das Fehlen eines Gender- oder feministischen Bewusstseins betonen - dass Gender in postkommunistischen Gesellschaften tatsächlich eine wichtige Determinante der Meinungen über die Geschlechterrollen ist: Wie auch anderswo bringen Frauen liberalere Einstellungen als Männer zum Ausdruck. Zweitens: Wir argumentieren, dass die Interaktion anderer Determinanten der Meinungen zu den Geschlechterrollen mit Gender gleichfalls den Mustern folgt, die in der Literatur im Bezug auf weiter entwickelte kapitalistische Gesellschaften beschrieben werden. In dieser Hinsicht scheinen die osteuropäischen Gesellschaften sich den allgemeinen Trends der Herausbildung von Meinungen zu den Geschlechterrollen anzugleichen. Zur Erklärung verweisen wir auf den Zusammenhang zwischen den materiellen Lebensbedingungen von Frauen und ihren Einstellungen zu den Geschlechterrollen, ohne jedoch die Bedeutsamkeit kultureller Unterschiede - wenn sie auch eher Ausnahmen sind - abzustreiten.

Schlagwörter: Gender, Einstellungen zu Geschlechterrollen, Zentral- und Osteuropa, Postkommunismus, Geschlechtergleichheit 
Researchers have demonstrated emerging differences in gender role attitudes between Eastern and Western European countries ${ }^{1}$ : a growing liberalization in Western Europe and what may be construed as a conservative anti-feminist turn in attitudes in much of the post-communist region (Einhorn 1993; Panayotova and Brayfield 1997; Takács 2008). Indeed, in an opinion survey conducted by the International Social Survey Program (ISSP) in 2002, the percentage of people who agreed or strongly agreed with the statement "A man's job is to earn money, a woman's job is to look after the home and the family" ranged from about $8-30 \%$ in Western European countries, and from $30-58 \%$ in post-communist East European societies ${ }^{2}$.

How people feel about the appropriate position of women and men in society is consequential for their behavior in all walks of life. Gender ideologies have been shown to be important in understanding emerging new and persisting old types of inequalities in Eastern Europe (Gal/Kligman 2000). New political regimes have used references to gender roles to indicate a break with the communist past and to legitimate their own rule (ibid). In different contexts "gender cultures" have been shown to correlate with a variety of institutional arrangements (Pfau-Effinger 1988), particularly welfare regime types (Haas 2005; Adler/Brayfield 2006), as well as with women's "individual" and "rational" choice to work for wages or not (Duncan/ Edwards 1997). In post-state socialist Eastern Europe in particular, the conservative turn in gender role attitudes has been blamed for the declining number of women in the labor force, the unequal division of labor in the household, and the low level of political representation of women in parliament. Researchers have particularly noted a strong opposition to the concept of feminism and a lack of political action and organization for women qua women (Einhorn 1993; Funk/Mueller 1993).

In this paper we explore the determinants of these conservative gender role attitudes in 13 Eastern European countries from the perspective of gender difference: Is there a gender gap in gender role attitudes in post-communist societies? Or do men and women agree on what women's role should be in the workplace and in the family? If women's ideas about their role in society coincide with those of men then gender is not a salient basis for political mobilization for gender equality. Researchers have claimed this to be the case in post-communist Eastern Europe (Einhorn 1993). If, however, men and women differ significantly in how they imagine women's and men's relationship to paid and unpaid work then perhaps a lack of feminist action in many East European countries may be less due to women's own desires and motivations, and more due to their perceived opportuni-

1 Here we use the term "Eastern Europe" with a capital E to designate not a geographical area, but the thirteen, formerly state socialist countries included in our project: Belarus, Bulgaria, the Czech Republic, Estonia, Hungary, Latvia, Lithuania, Moldova, Poland, Romania, Russia, Slovakia and Ukraine. "Western Europe", similarly refers not necessarily to a geographical area but to developed, historically capitalist countries in Europe and North America. This latter designation which ignores geography is not unique to this paper: One of the five regional commissions of the UN, the United Nations Economic Commission for Europe (UNECE) also includes the United States and Canada as its member states.

2 Figures based on authors' calculations using data from various waves of the ISSP's relevant modules and the website: http://zacat.gesis.org/webview/index.jsp. Note that East Germany is an exception to this with one of the lowest agreement rate $(15 \%)$ with the statement above, while West Germany is at the higher end of the scale for a Western European society (at 23\%). 
ties or individual interests. We therefore explore gender differences in gender role opinions in order to highlight potential fields of political action towards gender equality in a region that has - arguably - been plagued by a lack of feminist consciousness and mobilization since the end of World War II.

While in this paper our primary focus is the effect of a person's gender on his/her ideas about women's and men's place in society (what we will call "gender role opinions/ attitudes") in post-communist Eastern Europe, we also explore a number of other individual level factors (and their intersections with gender) that might shape - in indirect ways people's gender role opinions. Additionally, we briefly examine cross-country variations in the level of gender role opinions in the gender opinion gap because we suspect that these may be significant within the Central and Eastern Europe (CEE) region. We also contemplate the usefulness of macro-level factors explaining the above variations. For reasons we will explain later this is not the main focus of our analysis, but previous research has shown these macro-level factors to be of significance and possibly interacting with individual level gender difference (Baxter/Kane 1995; Brooks/Bolzendahl 2004).

We begin this paper with a brief overview of changes in gender role attitudes in Eastern Europe and continue by discussing what is known about its determinants from research on Western Europe. We develop our hypotheses from here. We also note the findings of the very small number of studies that used data from post-state socialist societies. Next, we move on to discuss our data and analytical strategy and continue with the analysis. We finish the paper by discussing the broader implications of our findings.

\section{Gender roles and gender role attitudes: The legacy of state socialism}

While in Western European countries the turn of the century witnessed a growing percentage of women entering the labor market and the promotion of social policy - if somewhat hesitantly - preparing to support this change (Esping-Andersen 2009), the opposite trend is widely noted in Eastern Europe after 1989. Women's labor force participation rates declined by approximately 20 to $25 \%$ in each of the thirteen countries observed, while party programs and policy makers distanced themselves from the state socialist emancipation project, which had emphasized the importance of paid work for all (Einhorn 1993).

Before 1989, most women of working age were in gainful employment in Eastern Europe work was an expectation of, occasionally a requirement for, state socialist citizens. Men's wages were not sufficient to support a family, and social benefits were often tied to labor force participation (Fodor 2003; Zimmermann 2010). Actual rates of employment varied. Occasionally this was simply a consequence of the particular definition of who counts as being part of the labor force or the "working age population", or due to the exact nature of parental leave policies and retirement age thresholds. Nevertheless, in general, women coming of age after 1949 were expected to spend most of their adult lives in paid full-time labor, with occasional breaks for having - an increasingly smaller number of - children. In most fields jobs were plentiful and the concept of open unemployment was non-existent. Comprehensive maternity leave policies allowed for breaks for childbirth, and guaranteed jobs upon return. Researchers argue that communist policy makers promoted the worker-mother ideal for women, where women's worker status was 
guaranteed and protected but expected to be at an inferior level compared to those of men (Fodor 2003; Ghodsee 2005; Weiner 2007). Women increasingly found work as low-level professionals in largely underpaid and undervalued jobs. The wages these jobs provided were a significant contribution to the family budget and the work hours were flexible enough - formally or informally - to allow taking time off for care work (Fodor 2003).

When the market replaced the state as the key agent allocating work, many of these positions disappeared and some were taken over by men. For example, the percentage of men employed in higher level positions in the financial sector grew as wage levels in this field started to increase. Overall, women's labor force participation rates declined and their general labor market position became more vulnerable, while balancing domestic and paid-work obligations has become harder to manage (UNIFEM 2006).

These trends were accompanied by a distinct change in mainstream gender ideology in the early 1990s as represented by policy makers and party leaders in power (Rueschemeyer 1998). The emphasis communist elites had placed on paid work as an important arena for women's contributions to society was replaced by arguments about the need for women's presence in the home and women's natural difference. The growing presence of the Catholic Church and right-wing conservative parties in political life also pushed public opinion in this direction in several countries. Newly minted post-communist politicians tended to distance themselves from the old regime by emphasizing their rejection of the women's emancipation agenda (Gal/Kligman 2000). Indeed, state policies followed these trends and researchers describe processes of welfare state re-traditionalization (Glass/ Fodor 2007) in a number of post-state socialist countries, which stands in sharp contrast to de-familialization trends observed elsewhere in Europe. The voices that called women to paid work seemed distant and lacking true political force - coming primarily from the European Union and other international agencies.

The change in "gender culture" has been tracked through examinations of gender role representations in magazines or political party programs in a variety of countries (Rueschemeyer 1998; True 2003). Here, however, we are concerned with how everyday women and men describe how they think about gender roles, whether these positions are different and how gender interacts with other factors in producing these views. In the next section, we describe patterns observed in historically capitalist countries as well as some recent studies from post-communist societies. On this basis, we develop the main research question as well as other hypotheses which will be tested.

\section{Theoretical considerations and the key hypothesis}

Researchers have identified a broad shift towards more liberal views on gender roles in numerous countries in the world (Inglehart/Norris 2000). "Liberal views" in this context mean that people are less likely to believe in the need for a sharp gender division in domestic and paid labor and are willing to grant a wider range of social choices for women. Proponents of "conservative views" would argue for strictly limited choices for both genders: women's primary role is naturally in the home, whereas men should act as breadwinners and providers for their families. Previous findings from around the world show a growing gender gap in gender role attitudes: women have become significantly more lib- 
eral than men and are increasingly more likely than their male counterparts to favor broadening opportunities outside the home as well as reducing gender inequality (Davis/ Robinson 1991; Davis/Joshi 1994; Panayotova/Brayfield 1997).

This gender gap in opinions is largely due to women's growing understanding of their own self-interest in changing traditional gender norms tied to their changing life situations. Baxter and Kane (1995) argue that while men in general have an interest in maintaining gender inequality and traditional gender roles, women who are less dependent on men are more likely to hold liberal views (see also Banaszak/ Putzer 1993). Specifically, women who have higher educational attainment and better employment opportunities, as well as those who live in countries where state support is available for the maintenance of households independent of men, have an interest in liberalizing gender roles as these help their chances of social advancement in their own right. As women are becoming less and less dependent on men financially, and more educated in general, we expect to see more support for liberal gender roles among them. While some men may also enjoy the advantages of the resources working wives bring to the family (Bolzendahl/Myers 2004), it is women who are expected to benefit more directly and thus to be more likely to express liberal gender roles.

Similar predictions about a gender gap in opinions follow from the hypothesis that rather than self-interest, exposure to specific life situations - such as discriminatory behavior or networking among other women - has contributed to the liberalization of attitudes among women (ibid). Women, when participating in education and the labor market, may become aware of these problems, and are exposed to a wider range of attractive opportunities available. Hence, the trend towards the liberalization of gender roles is expected to be spearheaded by women's changing attitudes.

The above arguments are based on research conducted in Western European countries. Our central research question is whether or not a similar gender difference (or gender gap) exists in opinion formation around gender roles in post-state socialist societies. This question has a number of theoretical implications of which we will discuss two related ones below: the salience of gender as a factor in gender role attitudes and the question of whether a convergence is observable in European (as well as in other developed) societies in their cultural predispositions in this regard (Inglehart/Norris 2003).

Researchers have noted a trend towards gender role conservatism rather than liberalization in at least some of the post-state socialist countries (Blaskó 2005). This phenomenon is in line with the hypothesis which expects the gender gap to be larger in countries which allow a higher degree of independence for women. As a large number of women lost their jobs and withdrew from the labor market in CEE after 1990 their dependence on their families grew. With this their interest in the domestic "patriarchal bargain" may have increased and their attachment to liberal gender roles decreased. Many women may have understood that the family, rather than the state or the labor market offers the best protection against destitution. In this sense, a growing conservatism in general, and a convergence in the opinion of men and women in particular may be understandable in Eastern Europe, even though the opposite has been found elsewhere.

Central and Eastern European women have repeatedly been blamed for not developing an interest and a political consciousness distinct from that of men. Feminist political observers started to ponder the lack of a "feminist consciousness" immediately after the collapse of the communist regimes (Funk/Mueller 1993). Indeed international activists 
and researchers were dissatisfied with the fact that women in Eastern Europe seem to have taken the growing waves of open discrimination lying down: only a small number of civic organizations were formed with the goal of fighting for women's increased social participation and even fewer of these called themselves feminists (Einhorn 1993). Women seemed to be reluctant to recognize shared interests (especially beyond those involving reproductive rights), and have been slow to mobilize around issues related to the workplace or political power (Matland/Montgomery 2003). Women's representation in public office is strikingly low in some of the countries in the region (ibid). Certainly, when asked in interviews, Hungarian female politicians in the early 1990s vehemently denied the significance of being women and the usefulness of gender as a political category (Éva Fodor's interviews in Hungary in the early 1990s).

Indeed, existing research does not explicitly show "convergence" between East and West European countries in terms of gender role opinions and in the gender gap in gender role opinions. Adler and Brayfield (2006), for example, have found that US attitudes have not converged to those held by Germans over the past years and - more importantly for our purposes here - while some convergence was observable, East German's and West German's gender role opinions were still quite far apart from each other.

Importantly, similarity in cultural positions ("convergence") may come about in different ways. When political observers or financial institutions use this term, the general idea is for East Europeans to "catch up" with the West in terms of institutional and economic development. Yet, the little longitudinally comparative data which exist raise the possibility of a different kind of convergence in gender role attitudes. The International Social Survey Program conducted a wave of surveys on gender role attitudes in 1988 before the collapse of the communist regimes, albeit only with a single East European country, Hungary, participating. A similar survey was repeated in 1994 and 2002. It is instructive to compare how Hungarians responded to questions on women's role in society compared to Western Europeans (Tóth 1997; Blaskó 2005). While Hungary is in no way representative of all state socialist countries, this is the only reliable historically comparative dataset available, which may be used to explore the phenomenon of "convergence" in gender role attitudes.

In 1988, Hungarians were significantly more likely than people in participating Western European countries (Austria, Germany, Great Britain, the Netherlands, Ireland and Italy) to agree that "A woman and her family will all be happier if she goes out to work". This is not surprising: Hungarian women's labor force participation rates were significantly higher than that of the women in the other participating countries. In addition, Hungarians were somewhat less likely than westerners to believe that preschool children will suffer if their mothers are working and more likely to feel that both husband and wife should contribute to the family income. Hungarians were also less likely than westerners (at least compared to those from Germany, Austria, Great Britain and the Netherlands) to say that women with preschool children should stay at home and not work for wages. Again, these were reflections of the realities Hungarian women and men faced before 1989: most mothers of preschool children worked full time, children after age 3 spent a full day in state-subsidized kindergartens and families could by no means get by on a single income of men alone.

Fourteen years later, in 2002 the difference between Hungarians and Western Europeans looked quite different: Westerners expressed more liberal views than Hungarians. 
This, however, is not only or not primarily because Hungarians have changed their views, but because westerners did. There is thus convergence but primarily due to changes in attitudes in Western European countries. In 1988, 52\% of Hungarians believed that moms with preschool kids should stay home. In $2002,46 \%$ did, a less than $10 \%$ decline. Yet in $1988,72 \%$ of Austrians, $76 \%$ of Germans, $70 \%$ of Britons and $56 \%$ of Dutch held this opinion, while in 2002 only $49 \%, 45 \%, 52 \%$ and $29 \%$, respectively, did. No doubt, Hungarians have changed, but westerners changed a great deal more. Similarly, while $85 \%$ of Hungarians believed in 1988 that both husband and wife should contribute to the household income, $80 \%$ did in 2002. But in Austria, for example, while $66 \%$ of the sample agreed in 1988, a whopping $82 \%$ did in 2002 . The change is smaller but still quite sizable in the other Western European countries, too.

As a result, in the 2002 ISSP survey there is little systematic difference between East and West in opinions held on whether or not mothers of preschoolers should stay at home or if both husband and wife should contribute to the household income. In some areas people from Hungary and other East European countries from which data are available in more recent waves of the ISSP ${ }^{3}$ are indeed more conservative: they are, for example, more likely than westerners to believe that "a man's job is work, a woman's is the household" and even that "what women really want is a home and children." But it is the opinion of Western Europeans that changed significantly towards a more liberal bend between 1988 and 2002, Hungarians did not or only barely express "more conservative" gender views than prior to 1989 . This means that the effects of the collapse of state socialism rather than contributing to a change in gender role opinions - in fact did the opposite: it froze gender role attitudes at the point of collapse. At the same time, major changes reshaped how people think about men's and women's role in society in developed capitalist countries, moving gender ideologies closer, rather than farther from each other. Indeed, this suggests convergence - albeit through somewhat different processes than usually described - between different regions of Europe in terms of overall gender role attitudes. At the same time, this also allows for the possibility that the gender gap in opinions did not converge and women are more or just as conservative as men in Eastern Europe - no matter how men's and women's opinions may have changed in the West - the question of our primary interest in this paper.

At the same time there are some good reasons to expect that changes in gender role expectations have taken place at least in some of the countries since the early 1990s in Eastern Europe also. Even though the rhetoric of women's emancipation kept gender conflict and the expression of feminist ideas at bay under communism, women may nevertheless have grown to identify economic interests different from that of men. After 1990 while women's dependence on families grew, the precariousness of this dependence also became clear. Marriage rates are lower than ever in all of the countries in the region, single motherhood and out-of-wedlock births are on the rise. Men's life expectancy has not kept up with the growth in women's and has in fact declined in some of the countries. In such a context women may recognize a growing interest in the spread of more liberal gender roles, which normalize and encourage their full participation in the labor market

3 Findings from other surveys, such as the European Social Survey are largely similar, although show a higher degree of conservatism in some areas in post-state socialist countries. 
and public life. The emergence of feminist groups as well as the increasing number of women in political positions (for example in Poland, where over $20 \%$ of members of parliament are women) may be a sign of these changes.

Our central question addresses the empirical and theoretical dilemma described above: Is there a gender gap in how men and women think about women's and men's role in society in Central and Eastern Europe? Additionally, do the same factors shape gender role opinions in post-communist societies as the ones which have been found relevant in post-industrial Western Europe?

\section{Additional hypotheses}

What factors in addition to gender explain variations in how people think about gender roles? Our hypotheses, based on existing literature, are described below.

Education and labor force participation are expected to have a positive impact on gender role liberalization in East European societies (Bolzendahl/Myers 2004). Both of these are expected to put men and women in touch with a diverse set of opinions as well as empower them to aspire for independence which, in turn, is better represented by liberal gender role opinions. Women may be affected more by these factors than men (Davis/Robinson 1991; Davis/Joshi 1994; Panayotova/Brayfield 1997).

Younger people (or more recent cohorts) are likely to hold more liberal views. Some researchers argue that this is due to a difference in their value socialization, others argue for differences in the social context in which they grew up (Brooks/ Bolzendahl 2004). Either way, age is expected to be a significant factor for both genders. Religious people are likely to hold more restricted opinions on women's role in society, especially if they belong to the Catholic Church, whose position on women may influence people towards conservatism more than other religions (Voicu/Voicu/Strapcova 2008). Women are often more influenced by religion than men, thus we expect this factor to push women into a conservative direction more than men.

Family status will also be correlated with gender role attitudes. Single people, independent of age, are more liberal than married ones, especially married people with children (Bolzendahl/Myers 2004). The marriage conservatism effect is expected to be more pronounced for women than men (Baxter/Kane 1995). This may be so because women's higher degree of dependence on men might be a cause, rather than the effect of marital status. The expectation about the effect of children is more mixed. Women may turn towards more conservative attitudes once they have children as their dependence on men increases. Moreover, the presence of children has been found to create a context in which women expect more participation from their spouses, thus opening the possibility of conflict and a move away from more traditional gender roles (Bolzendahl/Myers 2004). Finally, the location of residence has been found important: those living in rural environments are likely to support more conservative gender roles than those living in urban areas (Frieze/Ferligoj et al. 2003). This is expected to be similar for both men and women (Bolzendahl/Myers 2004). 


\section{Data and methods}

\section{Data, variables}

The data for this paper came from the project EUREQUAL, a thirteen-country international comparative dataset, funded by the European Commission's FP6 framework program. Using the same questionnaire ${ }^{4}$, local research agencies collected representative data in 2007 from Belarus, Bulgaria, the Czech Republic, Estonia, Hungary, Latvia, Lithuania, Moldova, Poland, Romania, Russia, Slovakia and Ukraine with N's around 1000 in most countries, except for Russia $(\mathrm{n}=2000)$ and Ukraine, Poland and Romania (where the sample size is around 1500), total $n=15,648$. The questionnaire primarily contained questions about people's views on politics and social inequality as well as on their own position in the social hierarchy.

The dependent variable for this project is called "liberal gender role opinions." This variable is a scale constructed by calculating the simple mean of answers to four questions, often employed in surveys to measure gender role opinions. Respondents had to decide whether or not they agree or disagree with the following statements using a scale of 1 to 5: "Both men and women should contribute to the family budget"; "A man's job is to earn money and a women's job is to look after the household and the family"; "Men should do more housework than they do now"; "Men should do more childcare than they do now". The scale's values range from 1 to 5 with a mean of 3.58 and a standard deviation of .59. (Cronbach's alpha is .61.)

Among the independent variables, education was coded as a set of three dummy variables; low level education, secondary education and tertiary level education completed. We first used local coding for the education variable, which then was translated into the international coding scheme ISCED-97. About $20 \%$ of the international sample had higher education, about 50\% medium level and 30\% lower level or less (see Table 2). Note that there is almost no difference between men and women in the level of education attained. Age was coded in years and ranged from 15 to 94 years, with a mean over 47 years. We constructed dummy variables to distinguish urban and rural residence using the characteristics of each country ${ }^{5}$. Over $68 \%$ of our respondents live in urban areas.

Religiosity, or, rather, church going was also coded as a dummy: if a respondent claimed to attend church at least once a month s/he was considered religious, otherwise not. Women proved to be much more active church-goers than men: over $35 \%$ of women but fewer than $25 \%$ of men claimed to be going to church regularly.

Marital status was coded as 1 if the respondent was married or living in a consensual union with a partner, and 0 if single, separated or divorced. Men are more likely to be married in our sample, reflecting differences in mortality rates and life expectancy. We are interested in the effect of the presence of children in the household, so a variable meas-

4 For more information on data collection procedures, see the project website at http://eurequal. politics.ox.ac.uk/.

5 In the survey, data were collected about the exact size of the settlement where the respondent lived. The variable urban/rural was constructed using this along with information from each country team about what constitutes "urban" in each country. 
ures the number of children under 16 who live together with the respondent. A further dummy variable was constructed to measure the respondents' labor market status: we differentiated those who claimed to be working for wages from those who did not. A larger percentage of men $(61 \%)$ than women $(49 \%)$ are employed in our samples. In addition, we attempted to measure the respondents' level of perceived economic vulnerability by using a subjective indicator. If a respondent claimed that his/her family did not always have enough money to eat or to buy clothes when needed, we coded the family as "poor" . We used dummy variables for each country and constructed interaction effects for the countries and gender to be used in some of the models described below.

\section{Data analysis and discussion}

\section{Does gender matter?}

Table 1 provides a preliminary answer to our main research question and it allows us to address the question of cross-national comparisons as well. The average score of liberal gender role opinions varies between 3.51 and 3.75. Countries where people in general hold more conservative views are Moldova, Hungary, Lithuania, Russia and Bulgaria, while countries with more liberal opinions include the Czech Republic, Poland, Slovakia and Ukraine. The gender gap varies even less: women are about 4 to $10 \%$ more likely than men to support liberal gender roles in each of the countries, with Moldova showing the smallest and Slovakia, Russia, and Poland the largest gap. If we exclude Moldova, where people seem to hold conservative views and there does not seem to be much difference between men and women in this regard, we find very little cross-country variation in the gender opinion gap. Indeed, our initial goal was to model - in hierarchical linear models, simultaneously with individual factors - macro-level determinants of cross-country variations in the gender difference (gender gap) in gender role opinions but we found very little variation to model. The interclass correlation (ICC) turned out to be a meager 3\% in the Null model during our hierarchical liner modeling attempts. Thus, we decided to focus on individual-level determinants only.

It is still instructive to take a brief look at cross-country variations in the mean level of gender role liberalism if only to gain ideas for future studies with larger datasets and better specified dependent variables ${ }^{7}$. A number of hypotheses have been put forward to

6 We opted to use this measure of socio-economic status instead of the more usual class-based classification because we did not have reliable and comparable income data in this dataset. Other class classifications are based on a person's job and since we only had information about the respondents' current job titles we would have excluded too many people from the analysis. This is also the reason why we do not include the respondents' occupation in the models. In any case, we believe that, especially in the countries we study, the combination of employment status with educational attainment is a good approximation of one's socio-economic status.

7 There are only a handful of studies examining cross-country differences in gender role attitudes which include East European countries as well, but at least one study, comparing Hungary and the United States found significant differences in the direction predicted by the economic development hypothesis (Panayotova/Brayfield 1997). Another study comparing Croatia, Slovenia and the US has more mixed findings but at least Croatia, the least developed of these countries, was found to be 
explain similar cross-country variations in other contexts. Inglehart and Norris (2003), for example, have shown levels of economic development to correlate with how people think about gender roles. They argue, based on an examination of data from the World Values Survey, that more developed post-industrial societies exhibit a tendency towards more liberal gender roles, although not necessarily a larger gap between men and women. This hypothesis is supported by our data as well, especially if we remove Hungary, a major outlier, from the dataset ${ }^{8}$. The countries with higher levels of economic development do exhibit more liberal gender role opinions. In the countries we examined there is no systematic variation between level of economic development and women's educational attainment, i.e. it is not true that women are more likely to be engaged in paid work in more economically advanced societies. Thus, the association between economic development and liberal gender role opinions is possibly explained by other factors. These could include easier access to liberal/feminist ideas in countries with a higher level of development or the perception of a wider range of opportunities there. To the extent that the generosity of welfare spending is associated with economic development, it is also possible that better state subsidies in richer countries may allow more women to establish independent households who would, in turn, be more likely to support the increase of public sphere opportunities for women.

In addition to the level of economic development we also found the level of religiosity (with the exception of Poland) and the level of welfare spending to correlate with liberal gender role opinions: in less religious countries and in countries with higher welfare spending people tend to hold more liberal gender role opinions. These results, however, are only based on a first glance at the cross-country variations in this dataset, which is too small for rigorous multi-level analysis. They are simply presented here to familiarize the reader with the dataset, and to offer ideas for further analysis.

\section{Regression models: the impact of gender in a multivariate context}

Shifting the focus of our analysis to the examination of whether there is a gender difference - net of other factors - in gender role opinions in the 13 countries of our study, Table 3 presents three linear regression models with liberal gender role opinions as the dependent variable. A high value on this scale, which ranges from 1 to 5 with an overall mean of 3.58 (S.d. .59), means more liberal gender role attitudes.

Model 1 describes the effect of gender without regard to any other factor except dummy variables for the countries. Moldova, which has the lowest mean score and the lowest gender gap in liberal gender role attitudes, is the omitted category. This model explains $7 \%$ of the variation in the dependent variable, women on average score .26 higher than men on the attitude scale. This confirms our findings in Table 1 that in poststate socialist Eastern Europe there is in fact a gender gap in gender role opinions with women holding more liberal views than men.

more conservative on some variables (Istenič 2007). A comparison of mainland China and Taiwan also does not yield clear predictions (Tu /Liao 2005).

8 This is based on the examination of simple scatterplots of the means of liberal gender role opinions with GDP per capita in each country. 
Model 2 includes all the control factors and the dummy variables for each country (except the excluded one, Moldova). This model explains somewhat more, about $9.5 \%$ of the variation. The issue of interest here is that gender is still positive and significant: women, net of other factors, still score .26 higher than men on the liberal gender role opinion scale. We should point out that we ran the same model separately for each of the countries and the variable gender turned out to be significant everywhere. This is to reject the possibility that large gender gaps in some countries "wash out" a lack of gender difference elsewhere.

In addition to gender, several other variables are also significant and work in the directions expected. People with higher education tend to hold more liberal views, as do people who live in cities, are younger, and are employed. Conversely, those who have more children in the household tend towards more conservative gender role attitudes. These variables are significant net of other factors, including the country averages. Feeling poor and being married (net of children) or attending church regularly does not make a difference.

Even with all the variables included, the explanatory power of these regression models is quite small. Previous research has usually managed to achieve an $\mathrm{R}$ square of around $20 \%$, i.e. they explain about twice the variation that the models in this article do (e.g. Baxter/Kane 1995, or Bohlzendahl/Myers 2004). This could be due to the omission of potentially important factors (such as, for example, details of employment characteristics or macro-level determinants of cross-country variations) or lack of detail on some variables (such as the type of religion a person identifies with or the exact character of family status, i.e. if the person is married or cohabiting in a consensual union, etc.).

It is important to observe the country level differences as shown in the coefficients associated with the country dummies. People in the Czech Republic, Poland and Slovakia score significantly higher than Moldovans (the excluded category), while Hungarians are not significantly different from Moldovans statsistically. These patterns will be familiar from the descriptive discussion above.

Model 3 in the same table includes interaction terms between gender and the country dummies. This is to assess the gender gaps in each country, controlling for all other factors. Moldova, with the smallest gender gap in the descriptive tables is omitted again. We find the results of our first analysis (Table 1) confirmed here: aside from Estonia, Latvia and Hungary, the interaction terms for all the other countries are significant with gender, meaning that their gender gaps are significantly larger than the one found in Moldova even net of all other factors. The impact of gender nevertheless remains significant as a main effect as well. It should also be noted that the model's fit is not improved by the addition of the country and gender interactions, supporting our point about the lack of cross-country variation in this regard.

\section{Interaction effects}

Finally, Table 4 describes similar regression models ran separately for men and women, examining whether or not the same predictors work in similar ways for the two gender groups in order to estimate gender role opinions. We did not include country dummies in the tables (even though they were included in the model with Moldova as the omitted 
category), since the country level gender gaps have been described in the models in Table 3 and in Table 1 . Now we focus on how gender interacts with the main independent variables in the models.

We find some interesting differences in how the usual determinants of gender role opinions work for men and women. First, employment is associated with more liberal opinions among women but not among men. This may be simply explained by the fact that the causal arrow runs in the directions opposite to what is usually posited. In post-state socialist countries, women who have conservative gender role opinions may choose not to work for wages or may classify themselves as non-working when asked by surveyers. More liberally minded women may do the opposite. Obviously, this association does not work for men. Alternatively, the differences could be due to the exceptionally liberating experience of working for wages for women as described in the literature (see above).

Second, and also in line with findings from Western European countries marriage seems to move women into the conservative, men into a more liberal direction. The effect for women may be explained by the level of dependence marriage sometimes produces for women, while men may become more liberal as they encounter themselves the problem of domestic work and childcare in their own families.

Finally, going to church regularly seems to push women towards more conservative values (or more conservative values seem to push women towards going to church), while the same impact cannot be discerned for men. Again, the causal arrow is unclear here but the association is clearly visible.

Overall, the model for women explains more of the individual level variation than the model for men, so the social factors included are better predictors of women's gender role opinions than those of men.

\section{Conclusion}

We started this paper wondering if gender is a salient predictor of gender role attitudes in post-state socialist societies. Previous researchers have argued that Eastern Europe is a special case in this regard: the legacy of forty-plus years of the communist emancipatory project led to a situation in which gender - while an important dimension of inequality nevertheless does not function as a dimension of political interest formation and political action. Indeed, the term "feminism" is considered pejorative and feminist organizations are rare to be found in the region (Šiklová 1993). Neither are there strong lobbying groups promoting women's issues or even party-affiliated women's groups with their own agenda for the betterment of women's position in society.

Our data, however, show that men and women do express different opinions on their proper role in society. Even after controlling for compositional factors, women in each country support women's wage earning and extra-domestic activities more strongly than men do. In addition, women more than men would favor a redistribution of domestic responsibilities, so not only do they find it legitimate for women to participate in public life, they also favor men's increased presence in the domestic sphere.

While this general trend is true for all the countries (except Moldova), we also found some variation across the countries in the level of gender conservativism and - less so - 
in the size of the gender opinion gap. We found that, with some exceptions, the level of economic development and the average level of religiosity are associated with gender role attitudes: on average both men and women in richer and less religious countries tend to exhibit more liberal gender role attitudes. This phenomenon, as well as the impact of gender and the other independent variables in our models, are in line with findings from developed capitalist societies. In this respect, therefore, Eastern Europe does not seem to form a unique region on the European continent but fits the general trends found elsewhere. While women may not call themselves "feminists" when asked by researchers, they - more than their fellow countrymen - would opt to work for wages and share domestic work with their husbands. These views, as anywhere else, can be the basis of political mobilization on the basis of gender in the future.

In fact, gender proved to be a salient dimension of political opinion formation in the 13 countries not only with respect to gender roles but also regarding other types of political views more typically considered "political" by researchers. In regression models not presented here but conducted by using data from the same dataset, we found East European women to be more likely than men to support a stronger role for the state and to reject neoliberalism. They were also more likely than men to support abortion rights and tended to place themselves more to the left on a left-right political scale. These differences further suggest that gender operates as an important dimension of political opinion formation in a number of areas not just gender roles.

The fact that political parties, lobbying groups and civil activists have not managed to mobilize women as a political group is thus not simply due to women's lack of understanding of their gender-specific interest, but rather to the ways and the processes through which political lobbying and mobilization has been taking shape in Eastern Europe.

Our research raised a number of questions, which would warrant further analysis. Most importantly, the question of cross-country variation in the mean level of gender role conservatism/liberalism should be explored in a dataset where more than 13 cases are available for analysis on the macro level, or where a larger set of questions could tap gender role attitudes in a more nuanced ways. It would be instructive to see if our initial findings about the role of economic development, welfare state support and Catholic ideology are indeed associated with a higher degree of conservatism. Secondly, in this paper we assumed that there is a connection between gender role opinions and at least the potential of political mobilization for (feminist) action. The nature, shape and potentials of this connection should also be studied, since, by identifying the deterimants of gender role opinions, our goal has been less to describe particular political cultures in post-communist societies, but more to identify opportunities for feminist action in a region where this is not generally expected.

\section{References}

Adler, M. A. \& Brayfield, A. (2006). Gender regimes and cultures of care: Public support for maternal employment in Germany and the United States. Marriage \& Family Review, 39, 4, pp. 229-253.

Banaszak, L. A. \& Putzer, E. (1993). Contextual determinants of feminist attitudes: National and subnational influences in Western Europe. American Political Scenece Review 87, 1, pp. 147-157. 
Baxter, J. \& Kane, E. W. (1995). Dependence and independence: A cross-national analysis of gender inequality and gender attitudes. Gender and Society 9, 2, pp. 193-215.

Blaskó, Z. (2005). Dolgozzanak-e a nők? A magyar lakosság nemi szerepekkel kapcsolatos véleményének változásai 1988, 1994, 2002. [Should women work? Changes in gender role opnions in Hungary]. Demográfia, 48, 2-3, pp. 159-186.

Bolzendahl, C. I. \& Myers, D. J. (2004). Feminist attitudes and support for gender equality: Opinion change in women and men, 1974-1998. Social Forces, 83, 2, pp. 759-790.

Brooks, C. \& Bolzendahl, C. (2004). The transformation of US gender role attitudes: Cohort replacement, social-structural change, and ideological learning. Social Science Research, 33, pp. 106-133.

Davis, H. \& Joshi, H. (1994). Sex, sharing and the distribution of income. Journal of Social Policy, 23, 3, pp. 301-340.

Davis, N. J. \& Robinson, R. V. (1991). Men's and women's consciousness of gender inequality: Austria, West Germany, Great Britain and the United States. American Sociological Review 56, pp. 72-84.

Duncan, S. \& Edwards, R. (1997). Lone mothers and paid work - Rational economic man or gendered moral rationalities? Feminist Economics, 3, 2, pp. 29-61.

Einhorn, B. (1993). Cindarella goes to market: Citizenship, gender and women's movements in East Central Europe. London \& New York: Verso.

Esping-Andersen, G. (2009). The incomplete revolution: Adapting to women's new roles. Cambridge, UK: Polity Press.

Fodor, É. (2003). Working difference: Women's working lives in Hungary and Austria, 1945-1995. Durham, NC: Duke University Press.

Frieze, I. H., Ferligoj, A. et al. (2003). Gender-role attitudes in university students in the United States, Slovenia, and Croatia. Psychology of Women Quarterly, 27, pp. 256-261.

Funk, N. \& Mueller, M. (Eds) (1993). Gender politics and post-communism: Reflections from Eastern Europe and the former Soviet Union. New York: Routledge.

Gal, S. \& Kligman, G. (2000). The politics of gender after socialism. Princeton, NJ: Princeton University Press.

Ghodsee, K. (2005). The Red Riviera: Gender, tourism, and postsocialism on the Black Sea. Durham, NC: Duke University Press.

Glass, C. \& Fodor, É. (2007). From public to private maternalism? Gender and welfare in Poland and Hungary after 1989. Social Politics, 14, pp. 323-350.

Haas, B. (2005). The work-care balance: Is it possible to identify typologies from cross-national comparison? Current Sociology, 53, 3, pp. 487-508.

Inglehart, R. \& Norris, P. (2000). The developmental theory of the gender gap: Women's and men's voting behavior in global perspective. International Political Science Review, 21, 4, pp. 441-463.

Inglehart, R. F. \& Norris, P. (2003). Rising tide: Gender equality and cultural change around the world. New York, NY: Cambridge University Press.

Istenič, M. Č. (2007). Attitudes towards gender roles and gender role behavior among urban, rural and farm populations in Slovenia. Journal of Comparative Family Studies, June, pp. 477-496.

Matland, R. E. \& Montgomery, K. A. (2003). Recruiting women to national legislatures: A general framework with applications to post-communist democracies. In: E. R. Matland \& K. A. Montgomery (Eds), Women's access to political power in post-communist Europe. Oxford, UK: Oxford University Press, pp. 19-43.

Orloff, A. S. (1993). Gender and the social rights of citizenship. American Sociological Review, 58, pp. 303-328.

Panayotova, E. \& Brayfield, A. (1997). National context and gender ideology: Attitudes toward women's employment in Hungary and the United States. Gender \& Society, 11, 5, pp. 627-655.

Pfau-Effinger, B. (1988). Gender cultures and the gender arrangement. A theoretical framework for cross-national comparison on gender. Innovation: The European Journal of Social Sciences (Special issue: The spatiality of gender), 11, 2, pp. 147-66.

Rueschemeyer, M., (Ed.) (1998). Women in the politics of postcommunist Eastern Europe. Armonk, NY: M.E. Sharpe. 
Šiklová, J. (1993). Are women in Central and Eastern Europe conservative? In: N. Funk \& M. Mueller (Eds), Gender, politics and post-communism. Reflections from Eastern Europe and the former Soviet Union. New York, NY, Routledge, pp. 74-83.

Takács, J. (2008). "Ha a mosogatógép nem lenne, már elváltunk volna...”: Férfiak és nők otthoni munkamegosztása európai öszehasonlításban ["If we didn’t have a dishwasher, we would be divorced by now...": The gender division of labor in the household in a European comparative perspective]. Esély, 6, pp. 51-73.

Tóth, O. (1997) Working women: Changing roles, changing attitudes. Hungarian Quarterly 38, http:// www.hungarianquarterly.com/no147/p69.shtml.

True, J. (2003). Globalization, gender and post-socialism. New York, NY: Columbia University Press.

Tu, S.-H. \& Liao, P.-S. (2005). Gender difference in gender-role attitudes: A comparative analysis of Taiwan and coastal China. Journal of Comparative Family Studies, September, pp. 619-640.

UNIFEM (United Nations Development Fund for Women) (2006). The story behind the numbers: Women and employment in Central and Eastern Europe and the Western Commonwealth of Independent States. Bratislava: UNIFEM.

Voicu, M., Voicu, B. \& Strapcova, K. (2008). Housework and gender inequality in European countries. European Sociological Review, 25, 3, pp. 365-377.

Weiner, E. S. (2007). Market dreams: Gender, class and capitalism in the Czech Republic. Ann Arbor, MI: University of Michigan Press.

Zimmermann, S. (2010). Gender regime and gender struggle in Hungarian state socialism. Aspasia. International Yearbook for Women's and Gender History of Central, Eastern and South Eastern Europe. 4, Spring, pp. 1-24.

Submitted on/Eingereicht am: 30.032010

Accepted on/Angenommen am: 22.10.2010

Addresses of the authors/Anschriften der Autorinnen:

Éva Fodor, Ph.D.

Department of Gender Studies

Central European University (Közép-európai Egyetem)

Nádor utca 9

1051 Budapest

Hungary/Ungarn

E-Mail: fodore@ceu.hu

Anikó Balogh, Ph.D. candidate

TÁRKI Social Research Institute

Budaörsi út 45

1112 Budapest

Hungary/Ungarn

E-Mail: aniko.balogh@tarki.hu 


\section{Appendix}

Table 1. Distribution of dependent variable across countries and overall

\begin{tabular}{lrcc}
\hline & N & $\begin{array}{r}\text { Liberal gender role scale } \\
\text { means (s.d.) }\end{array}$ & $\begin{array}{c}\text { Gender gap in liberal gender role opinion } \\
\text { (women's score/men's score) }\end{array}$ \\
\hline Belarus & 991 & $3.59(.54)$ & 1.09 \\
Bulgaria & 988 & $3.51(.65)$ & 1.07 \\
Czech Republic & 987 & $3.75(.57)$ & 1.07 \\
Estonia & 1049 & $3.55(.54)$ & 1.08 \\
Hungary & 1028 & $3.43(.62)$ & 1.06 \\
Latvia & 996 & $3.61(.55)$ & 1.07 \\
Lithuania & 997 & $3.49(.51)$ & 1.08 \\
Moldova & 1014 & $3.41(.52)$ & 1.04 \\
Poland & 1497 & $3.72(.64)$ & 1.09 \\
Romania & 1484 & $3.60(.59)$ & 1.07 \\
Russia & 1986 & $3.52(.59)$ & 1.09 \\
Slovakia & 1026 & $3.65(.55)$ & 1.10 \\
Ukraine & 1499 & $3.64(.60)$ & 1.07 \\
Overall & 15,542 & $3.58(.59)$ & 1.07 \\
\hline Source: & & &
\end{tabular}

Source: EUREQUAL 2007, data weighted for each country separately.

Table 2. Percentages, means, and standard deviations of independent variables in the models

\begin{tabular}{lccccc}
\hline & Mean (total) & S.d. (total) & $\mathrm{N}$ & Mean/ s.d. for women & Mean/s.d. for men \\
\hline Gender (\% women) & 56.4 & - & 15,643 & - & - \\
Age (mean) & 47.1 & 17.7 & 15,635 & $47.7(17.8)$ & $46.2(17.6)$ \\
Rural & 37.3 & - & 15,611 & 35.9 & 36.9 \\
Higher education & 20.4 & - & 15,648 & 21.4 & 19.2 \\
Mid-level education & 46.9 & - & 15,648 & 46.8 & 47.0 \\
Active church-goer & 31.2 & - & 12,889 & 35.7 & 24.8 \\
Married & 58.5 & - & 15,642 & 53.7 & 64.8 \\
Number of children in household & 0.48 & .81 & 15,537 & $.51(.82)$ & $.44(.80)$ \\
Working for wages & 54.3 & - & 14,684 & 49.3 & 60.9 \\
Feels poor & 33.3 & - & 15,313 & 37.7 & 29.2 \\
\hline
\end{tabular}

N's for each of the thirteen countries:

Belarus: 1000, Bulgaria: 1000, Czech Republic: 994, Estonia: 1057, Hungary: 1030, Latvia: 1001, Lithuania: 1002, Moldova: 1042, Poland: 1498, Romania: 1492, Russia: 2000, Slovakia: 1032, Ukraine 1500 .

Source: EUREQUAL 2007, data weighted for each country separately. 
Table 3. Linear regression coefficients and standard errors predicting liberal gender role opinions, 13 post-state socialist societies, 2007

\begin{tabular}{|c|c|c|c|}
\hline & Model 1 & Model 2 & Model 3 \\
\hline \multirow[t]{2}{*}{ Women } & $.27^{\star \star}$ & $.27^{\star \star}$ & $.12^{* *}$ \\
\hline & $(.009)$ & $(.011)$ & $(.04)$ \\
\hline \multirow[t]{2}{*}{ Age } & - & $.000^{*}$ & $.000^{*}$ \\
\hline & & $(000)$ & $(000)$ \\
\hline \multirow[t]{2}{*}{ Rural location } & - & $-.08^{* *}$ & $-.08^{* *}$ \\
\hline & & $(.011)$ & $(.011)$ \\
\hline \multirow[t]{2}{*}{ Have higher education degree } & - & $.14^{\star *}$ & $.14^{\star *}$ \\
\hline & & $(.02)$ & $(.02)$ \\
\hline \multirow[t]{2}{*}{ Have secondary educational degree } & & $.08^{* *}$ & $.08^{* *}$ \\
\hline & & $(.01)$ & $(.01)$ \\
\hline \multirow[t]{2}{*}{ Married } & - & -.01 & -.01 \\
\hline & & $(.011)$ & $(.011)$ \\
\hline \multirow[t]{2}{*}{ Number of children in the household } & - & $-.02^{* *}$ & $-.02^{* *}$ \\
\hline & & $(.01)$ & $(.01)$ \\
\hline \multirow[t]{2}{*}{ Working for wages } & - & $.05^{\star \star}$ & $.05^{\star *}$ \\
\hline & & $(.012)$ & $(.013)$ \\
\hline \multirow[t]{2}{*}{ Feeling poor } & - & -.01 & -.01 \\
\hline & & $(.01)$ & $(.01)$ \\
\hline \multirow[t]{2}{*}{ Active church-goer } & - & -.01 & -.01 \\
\hline & & $(.01)$ & $(.01)$ \\
\hline Belarus & $.19^{* *}(.025)$ & $.12^{* *}(.03)$ & $.00(.05)$ \\
\hline Bulgaria & $.10^{\star \star}(.025)$ & $.07^{* *}(.03)$ & $-.04(.04)$ \\
\hline Czech Republic & $.37^{* *}(.025)$ & $.35^{\star \star}(.03)$ & $.26 * *(.05)$ \\
\hline Estonia & $.16^{\star \star}(.025)$ & $.07^{*}(.03)$ & $.03(.05)$ \\
\hline Hungary & $.03(.025)$ & $.02(.03)$ & $-.04(.05)$ \\
\hline Latvia & $.21^{\star *}(.025)$ & $.14^{* *}(.03)$ & $.09 *(.05)$ \\
\hline Lithuania & $.11^{* *}(.025)$ & $.06^{* *}(.03)$ & $-.03(.04)$ \\
\hline Poland & $.33^{* *}(.023)$ & $.32^{* *}(.03)$ & $.19^{* *}(.04)$ \\
\hline Romania & $.19^{\star *}(.023)$ & $.18^{* *}(.03)$ & $.08^{* *}(.04)$ \\
\hline Slovakia & $.25^{\star \star}(.025)$ & $.24^{* *}(.03)$ & $.11^{* *}(.05)$ \\
\hline Russia & $.13^{\star *}(.022)$ & $.06^{* *}(.02)$ & $-.06(.04)$ \\
\hline Ukraine & $.22^{* *}(.023)$ & $.16^{* \star}(.02)$ & $\left..04{ }^{*} .04\right)$ \\
\hline \multicolumn{3}{|l|}{ Gender* Belarus } & $.18^{* *}(.06)$ \\
\hline \multicolumn{3}{|l|}{ Gender* Bulgaria } & $.17^{* *}(.06)$ \\
\hline \multicolumn{3}{|l|}{ Gender*Czech Rep. } & $.14^{* *}(.07)$ \\
\hline \multicolumn{3}{|l|}{ GenderEstonia } & $.06(.07)$ \\
\hline \multicolumn{3}{|l|}{ Gender* Hungary } & $.09(.06)$ \\
\hline \multicolumn{3}{|l|}{ Gender*Latvia } & $.07(.06)$ \\
\hline \multicolumn{3}{|l|}{ Gender* Lithuania } & $.13^{\star *}(.06)$ \\
\hline \multicolumn{3}{|l|}{ Gender* Poland } & $.21^{* *}(.05)$ \\
\hline \multicolumn{3}{|l|}{ Gender*Romania } & $.16^{\star *}(.05)$ \\
\hline \multicolumn{3}{|l|}{ GenderSlovakia } & $.20 * *(.06)$ \\
\hline \multicolumn{3}{|l|}{ Gender*Russia } & $.20^{* *}(.05)$ \\
\hline \multicolumn{3}{|l|}{ Gender*Ukraine } & $.18^{* *}(.05)$ \\
\hline \multirow[t]{2}{*}{ Constant } & $3.25^{\star \star}$ & $3.37^{* *}$ & $3.46^{* *}$ \\
\hline & $(.019)$ & $(.038)$ & $(.046)$ \\
\hline $\mathrm{N}$ & 15,542 & 15,542 & 15,542 \\
\hline $\mathrm{R}$ square & .077 & .095 & .098 \\
\hline
\end{tabular}

** significant at the $\mathrm{p}<.001$ level; * $\mathrm{p}<.05$

Source: EUREQUAL 2007, data weighted for each country separately. 
Table 4. Linear regression coefficients and standard errors predicting liberal gender role opinions, for men and women separately.

\begin{tabular}{|c|c|c|}
\hline & Men & Women \\
\hline Age & $\begin{array}{l}.00 \\
(00)\end{array}$ & $\begin{array}{c}-.001^{* *} \\
(.00)\end{array}$ \\
\hline Rural location & $\begin{array}{l}-.07^{\star *} \\
(.018)\end{array}$ & $\begin{array}{l}-.09^{* *} \\
(.015)\end{array}$ \\
\hline Have higher education degree & $\begin{array}{l}.14^{* *} \\
(.02)\end{array}$ & $\begin{array}{l}.12^{* *} \\
(.02)\end{array}$ \\
\hline High secondary level education & $\begin{array}{l}.10^{\star *} \\
(.02)\end{array}$ & $\begin{array}{l}.06^{* *} \\
(.02)\end{array}$ \\
\hline Married & $\begin{array}{l}.03^{*} \\
(.02)\end{array}$ & $\begin{array}{c}-.05^{\star \star} \\
(.01)\end{array}$ \\
\hline Number of children in the household & $\begin{array}{c}-.03^{* *} \\
(.01)\end{array}$ & $\begin{array}{c}-.02^{* *} \\
(.01)\end{array}$ \\
\hline Working for wages & $\begin{array}{l}.01 \\
(.02)\end{array}$ & $\begin{array}{l}.08^{* *} \\
(.02)\end{array}$ \\
\hline Feeling poor & $\begin{array}{l}.01 \\
(.02)\end{array}$ & $\begin{array}{l}-.02^{*} \\
(.01)\end{array}$ \\
\hline Active church-goer & $\begin{array}{c}.03 \\
(.02)\end{array}$ & $\begin{array}{c}-.04^{* *} \\
(.01)\end{array}$ \\
\hline Constant & $\begin{array}{l}3.40^{\star *} \\
(.061)\end{array}$ & $\begin{array}{l}3.67^{* *} \\
(.048)\end{array}$ \\
\hline $\mathrm{N}$ & 6810 & 8822 \\
\hline R square & .037 & .075 \\
\hline
\end{tabular}

Note: country dummies have been omitted form the table but were included in the model. Country dummies for men's models are significant for the Czech Republic, Latvia, Poland, Romania and Slovakia, in these countries men score significantly higher than men in Moldova (the omitted category).

In the second model all country coefficients except for the one for Hungary and Estonia are significantly higher than in Moldova, i.e. women in all but these two countries score higher on the liberal gender role opinion scale than those in Moldova (the omitted category).

** significant at the $\mathrm{p}<.001$ level; * $\mathrm{p}<.05$

Source: EUREQUAL 2007, data weighted for each country separately. 